\title{
Conclusion to Part III: A Tafsīr about the First Woman's Fertility and Theological Vulnerability
}

Treating illness was, for the most part, deemed compatible with Islamic theological orthodoxy. But the desperation brought on by illness, the lack of consensus about how to understand illness, the frequent failure of medical treatments, and the "faith" and power dynamics implied in the relationship between patient and practitioner invested sickness and healing with theological repercussions which potentially skewed toward heterodoxy in one form or another. Women, who were physically separated from the authorized interpreters of Islam, and who were deemed by some to be mentally deficient in religious matters, were depicted as in even greater danger in this regard. The jurists' interpretation of the field of medicine, when augmented with concerns about the religious ignorance and heterodoxy of Muslim women, and coupled with concerns about the physically intimate nature of medical intervention, could put Muslim women seeking gynecological care in a particularly uncomfortable position. Moreover, for young women who were mothers and aspiring mothers, it might have been even more difficult to make a distinction between medical and religious practice and authority, since medical care focusing on fertility and menstruation was intertwined with women's social roles and their ritual purity. Physical robustness, sickness, and death, i.e. "medical issues" were likely to have been a constant concern in their religious lives - in the form of menstruation, pregnancy, miscarriage, birth, stillbirth, breastfeeding and infant mortality.

All of these themes are encapsulated in a story told about the first woman, Eve, and her involvement with the Devil, Iblīs. The story appears in many different iterations. ${ }^{738}$ The following are the versions recounted in al-Tabarī's (d. 310/ 923) history:

(1) According to . . . Samura b. Jundab: None of Eve's children survived. Therefore, she vowed that if one of her children were to survive, she would call him 'Abd al-Ḥārith [al-Ḥārith being one of Satan's names.] When a child of hers survived, she called him 'Abd al-Ḥārith. That was due to Satan's inspiration.

(2) According to . . . Ibn 'Abbās: Eve would give birth to Adam's children and make them worship God, calling them 'Abdallāh, 'Ubaydallāh, and the like. But then they would

738 These sources are referred to in an article by D. A. Spellberg, although she interprets the implications of the story differently. Spellberg, "Writing the Unwritten Life of the Islamic Eve: Menstruation and the Demonization of Motherhood," International Journal of Middle Eastern Studies 28 (1996), 305-24.

Ә OpenAccess. (C) 2020 Sara Verskin, published by De Gruyter. (cc))BY-NC-ND This work is licensed under the Creative Commons Attribution-NonCommercial-NoDerivatives 4.0 License. 
die. Now Iblīs came to her and to Adam and said: Were you to give them other names, they would survive. So, when she gave birth to a male child for Adam, they called him 'Abd alHāarith. In this context, God revealed His word (Q. 7:190) from "It is He Who created you from a single soul" until "the two set up for Him associates in connection with what He had given them" to the end of the verse.

(3) According to ... Sa‘īd b. Jubayr: When Eve became heavy with her first pregnancy, Satan came to her before she gave birth, and said: Eve, what is that in your womb? She said: I do not know. He asked: Where will it come out, from your nose, your eye, or your ear? She again replied: I do not know. He said: Don't you think, if it comes out healthy, you should obey me in whatever I command you? When she said: Yes, he said: Call him 'Abd al-Ḥārith! Iblīs - May God curse him! - was called al-Hārith. She agreed. Afterwards, she said to Adam: Someone came to me in my sleep and told me such and such. Adam said: That is Satan. Beware of him, for he is our enemy who drove us out of Paradise. Then Iblīs May God curse him! - came to her again and repeated what he had said before, and she agreed. When she gave birth to the child, God brought him out healthy. Yet, she called him 'Abd al-Hārith. This is [meant by] God's word: "They set up for Him associates in connection with what he had given them" to "And God is above your associating [others with him]."

(4) When [Sa'îd b. Jubayr] was asked whether Adam associated [others with God], he replied: God forbid that I should assume Adam did that! However, when Eve was heavy with child, Iblīs came and said to her: Where will this one come out, from your nose, your eye, or your mouth? He thereby caused her to despair [because she did not know and was afraid of what was going to happen]. Then he said: Don't you think that, when it comes out perfectly formed - Ibn Wakī' said that Ibn Fudayl added: without harming or killing you - you should obey me? When she agreed, he said: Call him 'Abd al-Hārith, and she did. Jarīr added: So Adam's associating [others with God] was only in the name.

(5) So she - meaning Eve - gave birth to a boy. Iblīs came to her and said: Call (plural) him my servant ('abdī)! If you don't, I shall kill him. Adam said to him: I obeyed you [once before], and you caused me to be driven out of Paradise. So he refused to obey him and called the child "Abd al-Rahman "Servant of the Merciful One." Satan - May God curse him! gained power over the boy and killed him. Eve bore another child, and when she gave birth to it, Satan said: Call him my servant! If you don't, I shall kill him. Adam said to him [again]: I obeyed you [once before], and you caused me to be driven out of Paradise. So he refused to obey him and called the boy Șālih, and Satan killed him. The third time around, Iblīs said to Adam and Eve: If you (pl.) want to overcome me, call him 'Abd alHāarith. Iblīs's name was al-Ḥārith. He was called Iblīs when he was bedeviled (ublisa) became confused. This [is meant by God's word] where He says: "They set up for him associates in connection with what He had given them" - meaning in connection with the names." 739

739 Franz Rosenthal, History of al-Tabari: General Introduction and From the Creation to the Flood (Albany: SUNY Press, 1989), 320 -2. Arabic: al-Tabarī, Tārīkh al-rusul wa'l-mulūk (Leiden: Brill, 1879), 1:149-51. 
Eve is quite literally hell-bent on producing a viable son. In versions (1), (2), and (5), her desperation stems from the fact that she has already experienced either pregnancy loss or infant death, ${ }^{740}$ despite the fact that (in versions 2 and 5) she had shown her devotion to the true God by naming her children as His servants. In versions (3) and (4) her desperation stems from her fears, prior to her first birth, about how childbirth works. Any audience of the story would recognize the fear that the thing in her body might emerge from her facial orifices as extremely naïve, although some might empathize with her ignorance about the physiology of birth and her inability to know what precisely is inhabiting her body. ${ }^{741}$ To a medieval audience, however, her fear that either her child or she herself might not survive the ordeal is perfectly sensible. In these respects, Eve's concern to ensure her own in health, the health of her child, and her success in giving "birth to a male child for Adam," is reflective of the concerns of medieval wives generally.

In versions (2) and (5), Adam and Eve find that their choice to name their child "the Servant of God," i.e. to show their dedication to true religion, does not result in health - their children die anyway. In response, either Eve or both parents call their child "the Servant of the Devil." This proves to be an effective course of action, for their children are healthy. The texts are of two opinions as to why this happened. In versions (1) and (2), the children dedicated to God die for no apparent reason. No foul play is mentioned but God simply does not choose to keep them alive. So Eve shops around for another source of health and settles on invoking Satan. In version (3), the child dedicated to Satan survives due to God's efforts, not Satan's, although Eve gives credit to Satan. In version (4) too, Eve gives credit to Satan, but it is unclear whether this is deserved or not. In version (5), the children dedicated to God are killed by Satan, while the one dedicated to Satan lives on. The children's ill-health is thus not a result of nature or Divine negligence, as Satan himself provides the disease. Adam and Eve are perfectly aware that Satan is the cause of their troubles, yet they choose to throw in their lot with him because he is ultimately more effective than God is

740 It is not clear from al-Ṭabarì's account when the death takes place. In Ibn Hanbal's account, which he traces to Samura ibn Jundab, Satan seems to kill the fetus in utero. Ahmad ibn Hanbal, Musnad (Cairo: n.p., 1895), 5:11.

741 In Ibn Sa'd's version of the story, Satan appears in disguise to Eve during one of her later pregnancies and tells her that unlike in her previous (successful pregnancies), this fetus is misformed like an animal, and she panics. He says he will heal the fetus if the child is named for him. Ibn Sa‘d, Tabaqāt, 1:14. A medieval audience, living in a period when endogamy and malnutrition were common, may have been particularly receptive to Eve's terror about her fetus' birth-defects. 
when it comes to securing their child's health. Remarkably, in all versions of the anecdote the decision to dedicate the child to Satan is depicted as a perfectly logical and effective course of action, if birthing successfully is the ultimate goal. ${ }^{742}$

In this story Satan is a figure who has the power to protect, who can understand things which Eve is at a loss to explain, who poses a threat which necessitates propitiation, and who offers a plausible alternative after a first attempt proves to be ineffective. In these respects, Satan is similar to both the "high" physicians and the "low" medical practitioners, and to their respective medical systems, as depicted by those jurists who consider them a threat. The jurists warn that these medical practitioners and systems may indeed be effective, and they may indeed offer knowledge which Islam seemingly lacks. The jurists also warn that sometimes malicious physicians in fact cause the illnesses which they purport to cure. And they recognize that Muslims turn to non-Islamic medicine because when people are sick they will turn to anyone and everyone. Even the Prophet, when he was sick, turned to both Muslims and non-Muslims for help.

In the story of Eve and her quest for healthy children, turning to Satan to keep her child healthy is one and the same thing as dedicating her child to Satan. There is no ultimate difference between the realm of abdān (bodies) and the realm of $\operatorname{din}$ (religion), except that God is seemingly less effective in the former than in the latter. It is not entirely clear whether Eve is aware that the individual she ultimately entrusts her health to is Satan. In version (5), she definitely is aware, but in versions (1), (2) and (4), Eve is "inspired" or instructed by someone whom she may or may not recognize, to change her child's name to 'Abd al-Haarith, but it is not at all clear that Eve is aware that al-Hārith is Satan's name. ${ }^{743}$ In version (3), Eve seems to be unaware until Adam explains that al-Hārith refers to the Devil. However, even with this information in hand she dedicates her son to al-Hārith thinking that it was he who caused her to give birth to a healthy child. In this respect too, Eve's relationship with Satan reflects the jurists' concerns about patient-provider relations. Patients may not realize that what they are doing constitutes shirk, and even once they do realize it they may no longer be concerned. In Eve's case, in version (3), she is rendered especially vulnerable because she, unlike her husband Adam, does not have direct knowledge about Satan's identity and about who does and does not constitute "the enemy." This too reflects the view held by jurists such as Ibn al-Haajj

742 The one exception is Ibn Sa'd's version in which 'Abd al-Ḥārith dies.

743 In Ibn Sa'd's version, it is explicitly stated that Satan cleverly refers to himself as al-Ḥārith so that Eve will not recognize him. 
that a woman, unlike her husband, does not have direct knowledge about what constitutes correct religious practice and hence has trouble identifying its opposite.

Denise Spellberg understands the above story as promoting "the demonization of motherhood." This is a plausible interpretation but, if so, the story does so in a very strange manner. Whereas Eve's other sin, the eating of the fruit of the forbidden tree and the "cutting" of the tree, is characterized as resulting from stupidity, appetite, or the desire to violate the divine order by acquiring immortality, this sin is characterized as the result of Eve's desire to achieve what is not only possible but also desirable for her as a wife - she would like to produce children for her husband. The story thus does not demonize motherhood so much as it depicts the ferociousness of mothers' dedication to their own fertility. They will turn to God to produce children but, if that fails, they will turn elsewhere too. 